\title{
CHARACTER BUILDING PADA MANUSIA (Analisis Terhadap Budaya Suku Dayak Losarang Indramayu)
}

\author{
Tarsono \\ UIN Sunan Gunung Djati Bandung, Jl. A.H. Nasution 105 \\ tarsonomuad@gmail.com
}

\begin{abstract}
Humans are unique creatures because they have a different character each other. The character is a strong trait of a man that its formation is influenced by their culture. The tribe of Dayak Losarang in Indramayu district is one of unique custom that located in urban area. Their uniqueness is including how to dress, how to communicate, how to worship and make sense of life. Push factors and pull factors that make them survive in indigenous communities are some rituals which are: a) kungkum, b) pepe, c) ngaula ning anak rabbi, d) ruatan putri keraton, e) pemurnian diri (self-purification), and f) Kliwon Friday night.
\end{abstract}

Keywords: character, custom, ritual

\begin{abstract}
Abstrak
Manusia merupakan makhluk yang unik karena memiliki karakter yang berbeda satu dengan lainnya. Karakter merupakan sifat yang kental pada manusia yang pembentukannya salah satunya dipengaruhi oleh budaya. Suku Dayak Losarang Kabupaten Indramayu merupakan suatu adat yang unik yang berada di lingkungan perkotaan. Keunikannya meliputi cara berpakaian, cara berkomunikasi, cara beribadah dan memaknai hidup. Faktor pendorong dan faktor penarik yang membuat mereka bertahan dalam kelompok masyarakat adat adalah beberapa ritualnya yaitu : a) Ritual Kungkum, b) ritual pepe, c) ngaula ning anak rabi, d) ritual ruatan putri keraton, e) pemurnian diri, dan f) ritual malam jumat kliwon
\end{abstract}

Kata Kunci : karakter, adat, ritual

\section{PENDAHULUAN}

Manusia merupakan salah satu makhluk, berarti sesuatu yang diciptakan, setiap yang diciptakan tentu ada penciptanya yaitu Allah. ${ }^{1}$ Manusia itu makhluk ciptaan Allah yang paling sempurna, paling mulia dibandingkan dengan makhluk lainnya, karena manusia dikaruniai oleh Allah SWT berupa akal, perasaan dan kehendak yang tidak dimiliki oleh makhluk lainnya. ${ }^{2}$ Oleh karena itu manusia harus sadar untuk kembali kepada fitrah manusia sebagai makhluk ciptaan Allah. Ia diciptakan dari dua unsur, unsur jasmani

\footnotetext{
${ }^{1}$ Kementrian Agama, Penciptaan Manusia, (Jakarta : Kementrian Agama RI , 2012), hlm 1

${ }^{2}$ Supriadi, Etika dan Tanggung Jawab Profesi Hukum di Indonesia, (Jakarta: Sinar Grafika, 2006). hlm.1.
}

dan rohani. Kedua unsur ini berkembang selaras dan seimbang. ${ }^{3}$

H.A.R. Tilar (2000:19-23) mengemukakan pokok-pokok paradigma baru pendidikan sebagai berikut: (1) pendidikan ditujukan untuk membentuk masyarakat Indonesia baru yang demokratis; (2) masyarakat demokratis memerlukan pendidikan yang dapat menumbuhkan individu dan masyarakat yang demokratis; (3) pendidikan diarahkan untuk mengembangkan tingkah laku yang menjawab tantangan internal dan global; (4) pendidikan harus mampu mengarahkan lahirnya suatu bangsa Indonesia yang bersatu serta demokratis; (5) di dalam

\footnotetext{
${ }^{3}$ Suwarno Imam S. Konsep Tuhan, Manusia, Mistik dalam Berbagai Kebatinan Jawa, (Jakarta: PT Raja Grafindo Persada, 2005, hlm VI
} 
menghadapi kehidupan global yang kompetitif dan inovatif, pendidikan harus mampu mengembangkan kemampuan berkompetisi di dalam rangka kerjasama; (6) pendidikan harus mampu mengembangkan kebhinekaan menuju kepada terciptanya suatu masyarakat Indonesia yang bersatu di atas kekayaan kebhinekaan masyarakat, dan (7) yang paling penting, pendidikan harus mampu meng-Indonesiakan masyarakat Indonesia sehingga setiap insan Indonesia merasa bangga menjadi warga negara Indonesia.

Pembinaan umat manusia mestinya tidak hanya mementingkan kemajuan intelektual semata, tetapi diimbangi dengan pembinaan kebatinan atau kerohanian. Kebatinan merupakan sistem kepercayaan yang dianut oleh sebagian masyarakat, khususnya suku Jawa. Karenanya kebatinan sering disebut " kejawen ". Munculnya berbagai macam aliran kebatinan yang demikian banyak jumlahnya, merupakan bentuk partisipasi dalam memperkuat jati diri dan kepribadian. Kebatinan adalah sumber asas dan sila Ketuhanan Yang Maha Esa untuk mencapai budi luhur guna kesempurnaan hidup. ${ }^{4}$

Kejawen memiliki tingkat kesadaran bahwa kebaikan-kebaikan yang dilakukan seseorang kepada sesama bukan atas alasan ketakutan dosa-neraka, melainkan kesadaran bahwa setiap perbuatan baik kepada sesama merupakan sikap adil dan baik pada diri sendiri. Kebaikan kita pada sesama adalah kebutuhan diri kita sendiri. Kebaikan akan berbuah kebaikan, karena setiap kebaikan yang kita lakukan pada sesama akan kembali untuk diri kita sendiri, bahkan satu kebaikan akan kembali pada diri kita secara berlipat. Demikian juga sebaliknya, setiap kejahatan akan berbuah kejahatan pula. Kita suka mempersulit orang lain, maka dalam urusan-urusan kita akan sering menemukan kesulitan. Kita gemar menolong

\footnotetext{
${ }^{4}$ Ibid, hlm. 85
}

dan membantu sesama, maka hidup kita akan selalu mendapatkan kemudahan. ${ }^{5}$

Begitupun dalam Komunitas Suku Dayak Losarang Indramayu, yang didirikan oleh Ki Takmad Diningrat. Mereka dalam kehidupannya selalu menolong dan membantu sesama. Komunitas ini terlihat unik, dikatakan demikian karena penampilan sehari-harinya hanya mengenakan celana katun sebatas lutut dengan paduan warna hitam dan putih. Mereka juga mengenakan aksesoris, seperti gelang dan kalung yang terbuat dari kayu. Sekilas penampilan mereka memang mirip dengan Suku Dayak di Kalimantan. Apalagi pelabelan nama dari Suku Dayak HinduBudha Bumi Segandhu atau bisa disebut juga dengan Komunitas Suku Dayak Losarang. Namun demikian, menurut pengakuan mereka tidak ada pertalian sama sekali dengan suku etnik yang berada di Kalimantan itu. Istilah Suku Dayak Hindu-Budha Bumi Segandhu tidaklah berdiri diatas makna pada umumnya melainkan di bangun diatas makna filosofi tersendiri. Kata suku bukanlah dalam arti etnik, melainkan dimaknai dengan kaki.

Bukan hanya itu, keunikan yang lain tampak terlihat dari beberapa ajarannya, salah satu dari ajaran dalam Komunitas Suku Dayak Losarang Indramayu ini adalah Ajaran Ngaji Rasa. Konsep ajaran ini tidak didasarkan pada kitab suci, aliran kepercayaan dan kebudayaan tertentu, melainkan dengan mengambil teladan tokohtokoh pewayangan yang dianggap oleh mereka sangat bertanggung jawab terhadap keluarga. Dengan ajaran ini mereka sangat menghormati wanita, bergaul secara terbuka, tanpa membedakan ras, suku keyakinan maupun agama. Komunitas ini memberi kesempatan kepada anggotanya untuk melakukan ngaji rasa. Dengan ajaran ini pula, mereka lebih mengutamakan introspeksi diri dari pada bersikap selalu menyalahkan orang lain.

Komunitas ini menempatkan alam sebagai posisi terhormat, sekaligus sebagai

\footnotetext{
${ }^{5}$ Ibid, hlm. 57
} 
inspirasi. Mereka hidup dengan pola kesederhanaan, dan meyakini bahwa kemewahan dunia hanya akan membuat hidupnya resah, dan kekayaan tidak begitu penting, yang paling penting ialah sabar, jujur, benar, dan dapat berbuat baik dengan sesama makhluk hidup. Komunitas ini mempunyai rasa kemanusiaan yang tinggi terhadap sesama makhluk Tuhan. Kesatuan dan kebersamaan mereka dianggap bisa menyatukan rasa gotong royong, tenggang rasa, dan peduli terhadap sesama makhluk Tuhan. Hal ini didasari oleh keyakinan bersama akan kebenaran ajaran yang diberikan oleh pemimpin mereka yaitu $\mathrm{Ki}$ Takmad Diningrat. Komunitas ini menganggap bahwa tidak ada perbedaan diantara mereka, duduk sama rendah berdiri sama tinggi. Samasama insan Tuhan. Hubungan yang harmonis antara sesama manusia dan lingkungannya akan selalu terjaga. ${ }^{6}$

\section{Kerangka Teori Pendidikan Karakter}

\section{Pengertian Pendidikan Karakter}

Pengertian karakter menurut $\mathrm{Pu}$ sat Bahasa Depdiknas adalah "bawaan, hati, jiwa, kepribadian, budi pekerti, perilaku, personalitas, sifat, tabiat, temperamen, watak". Adapun berkarakter adalah berkepribadian, berperilaku, bersifat, bertabiat, dan berwatak". Menurut Tadkiroatun Musfiroh (UNY, 2008), karakter mengacu kepada serangkaian sikap (attitudes), perilaku (behaviors), motivasi (motiva-tions), dan keterampilan (skills). Karakter berasal dari bahasa Yunani yang berarti " $t o$ mark" atau menandai dan memfokuskan bagaimana mengaplikasikan nilai kebaikan dalam bentuk tindakan atau tingkah laku, sehingga orang yang tidak jujur, kejam, rakus dan perilaku jelek lainnya dikatakan orang berkarakter jelek. Sebaliknya, orang yang

\footnotetext{
${ }^{6}$ Nur arianata, Konsep Ketuhanan Dalam Ajaran Komunitas Suku Dayak HinduBudha Bumi Segandhu Indramayu, (Skripsi Program Sarjana IAIN Syekh Nurjati Cirebon, 2012), hlm. 34
}

perilakunya sesuai dengan kaidah moral disebut dengan berkarakter mulia.

Karakter mulia berarti individu memiliki pengetahuan tentang potensi dirinya, yang ditandai dengan nilai-nilai seperti reflektif, percaya diri, rasional, logis, kritis, analitis, kreatif dan inovatif, mandiri, hidup sehat, bertanggung jawab, cinta ilmu, sabar, berhati-hati, rela berkorban, pemberani, dapat dipercaya, jujur, menepati janji, adil, rendah hati, malu berbuat salah, pemaaf, berhati lembut, setia, bekerja keras, tekun, ulet/gigih, teliti, berinisiatif, berpikir positif, disiplin, antisipatif, inisiatif, visioner, bersahaja, bersemangat, dinamis, hemat/efisien, menghargai waktu, pengabdian atau dedikatif, pengendalian diri, produktif, ramah, cinta keindahan (estetis), sportif, tabah, terbuka, tertib. Individu juga memiliki kesadaran untuk berbuat yang terbaik atau unggul, dan individu juga mampu bertindak sesuai potensi dan kesadarannya tersebut. Karakteristik adalah realisasi perkembangan positif sebagai individu (intelektual, emosional, sosial, etika, dan perilaku).

Individu yang berkarakter baik atau unggul adalah seseorang yang berusaha melakukan hal-hal yang terbaik terhadap Tuhan YME, dirinya, sesama, lingkungan, bangsa dan negara serta dunia internasional pada umumnya dengan mengoptimalkan potensi (pengetahuan) dirinya dan disertai dengan kesadaran, emosi dan motivasinya (perasaannya).

Pendidikan karakter adalah suatu sistem penanaman nilai-nilai karakter kepada warga sekolah yang meliputi komponen pengetahuan, kesadaran atau kemauan, dan tindakan untuk melaksanakan nilai-nilai tersebut. Pendidikan karakter dapat dimaknai sebagai "the deliberate use of all dimensions of school life to foster optimal character develop-ment". Dalam pendidikan karakter di sekolah, semua komponen (pemangku pendi- 
dikan) harus dilibatkan, termasuk komponen-komponen pendidikan itu sendiri, yaitu isi kurikulum, proses pembelajaran dan penilaian, penanganan atau pengelolaan mata pelajaran, pengelolaan sekolah, pelaksanaan aktivitas atau kegiatan ko-kurikuler, pemberdayaan sarana prasarana, pembiayaan, dan ethos kerja seluruh warga sekolah/lingkungan. Di samping itu, pendidikan karakter dimaknai sebagai suatu perilaku warga sekolah yang dalam menyelenggarakan pendidikan harus berkarakter.

Berdasarkan grand design yang dikembangkan Kemendiknas (2010), secara psikologis dan sosial kultural pembentukan karakter dalam diri individu merupakan fungsi dari seluruh potensi individu manusia (kognitif, afektif, konatif, dan psikomotorik) dalam konteks interaksi sosial kultural (dalam keluarga, sekolah, dan masyarakat) dan berlangsung sepanjang hayat. Konfigurasi karakter dalam konteks totalitas proses psikologis dan sosialkultural tersebut dapat dikelompok-kan dalam: Olah Hati (Spiritual and emotional development), Olah Pikir (intellectual development), Olah Raga dan Kinestetik (Physical and kinestetic development), dan Olah Rasa dan Karsa (Affective and Creativity development) yang secara diagramatik dapat digambar-kan sebagai berikut.

\begin{tabular}{cc}
\hline $\begin{array}{c}\text { OLAH PIKIR } \\
\text { (Cerdas) }\end{array}$ & $\begin{array}{c}\text { OLAH HATI } \\
\text { (Jujur Bertanggung } \\
\text { Jawab) }\end{array}$ \\
\hline OLAH RAGA & OLAH RASA dan \\
(KINESTETIK) & KARSA \\
(Bersih, Sehat, Menarik) & (Peduli dan Kreatif) \\
\hline
\end{tabular}

\section{Nilai Dasar dalam Pendidikan Ka- rakter}

Thomas Lickona mengemukakan bahwa "Memiliki pengetahuan nilai moral itu tidak cukup untuk menjadi manusia berkarakter, nilai moral harus disertai dengan adanya karakter yang bermoral" (1992: 53). "Termasuk dalam karakter ini adalah tiga komponen karakter (components of good character) yaitu pengetahuan tentang moral (moral knowing), perasaan tentang moral (moral feeling), dan perbuatan bermoral (moral actions)" (Nurul Zuriah, 2007: 45). Hal ini diperlukan agar manusia mampu memahami, merasakan, dan sekaligus mengerjakan nilai-nilai kabajikan.

\section{Jenis-jenis Pendidikan Karakter}

Ada empat jenis karakter yang selama ini dikenal dan dilaksanakan dalam proses pendidikan, yaitu:

a. pendidikan karakter berbasis nilai religius, yang merupakan kebenaran wahyu tuhan (konservasi moral).

b. pendidikan karakter berbasis nilai budaya, antara lain yang berupa budi pekerti, pancasila, apresiasi sastra, keteladanan tokoh-tokoh sejarah dan para pemimpin bangsa.

c. pendidikan karakter berbasis lingkungan (konservasi lingkungan).

d. pendidikan karakter berbasis potensi diri, yaitu sikap pribadi, hasil proses kesadaran pemberdayaan potensi diri yang diarahkan untuk meningkatkan kualitas pendidikan (konservasi humanis) (Yahya Khan, 2010:2).

\section{Fungsi Pendidikan Karakter}

Menurut Kementerian Pendidikan Nasional (2010: 7) fungsi pendidikan karakter adalah:

a. Pengembangan: pengembangan potensi peserta didik untuk menjadi pribadi berperilaku baik; ini bagi peserta didik yang telah memiliki sikap dan perilaku yang mencerminkan budaya dan karakter bangsa;

b. Perbaikan: memperkuat kiprah pendidikan nasional untuk bertanggung jawab dalam pengembangan potensi peserta didik yang lebih bermartabat; dan

c. Penyaring: untuk menyaring budaya bangsa sendiri dan budaya bangsa lain yang tidak sesuai dengan nilainilai budaya dan karakter bangsa yang bermartabat. 


\section{Tujuan Pendidikan Karakter}

Tujuan pendidikan karakter adalah:

a. Mengembangkan potensi kalbu atau nurani/afektif peserta didik sebagai manusia dan warganegara yang memiliki nilai-nilai budaya dan karakter bangsa;

b. Mengembangkan kebiasaan dan perilaku peserta didik yang terpuji dan sejalan dengan nilai-nilai universal dan tradisi budaya bangsa yang religius;

c. Menanamkan jiwa kepemimpinan dan tanggung jawab peserta didik sebagai generasi penerus bangsa;

d. Mengembangkan kemampuan peserta didik menjadi manusia yang mandiri, kreatif, berwawasan kebangsaan; dan

e. Mengembangkan lingkungan kehidupan sekolah sebagai lingkungan belajar yang aman, jujur, penuh kreativitas dan persahabatan, serta dengan rasa kebangsaan yang tinggi dan penuh kekuatan (dignity) (Ibid, 2010)

\section{Masyarakat}

Manusia sebagai makhluk sosial maupun tersusun dalam kelompokkelompok. Fakta ini menunjukkan manusia mempunyai sosial dan pembawaan kemasyarakatan (sejumlah sifat-sifat dapat berkembang dalam pergaulan dengan sesamanya) seperti hasrat bergaul dan sebagainya. Kecenderungan sosial ini merupakan keanehan, yaitu perasaan yang lain misalnya harga diri. Rasa harga diri tampak sebagai keinginan untuk berharga tetapi juga keliatan berharga.

Suatu himpunan manusia merupakan kelompok sosial yang harus memenuhi syarat-syarat, antara lain:

1. Setiap anggotanya harus sadar bahwa ia merupakan bagian dari kelompoknya.

2. Ada hubungan timbal balik antara anggota-anggotanya.

3. Ada suatu faktor yang dimiliki bersama, seperti nasib yang sama, kepentingan yang sama, tujuan yang sama, dan sebaginya.
Jadi masyarakat itu dibentuk oleh individu-individu yang berada dalam keadaan sadar. Individu-individu yang hilang ingatan, individu-individu yang pikirannya rusak, individu-individu tipe ini tidak dapat menjadi anggota masyarakat yang permanen, melainkan hanya kepada meraka yang benar-benar saling mengikat dirinya dengan individu-individu lainnya. Membentuk satu kesatuan dapat disebut individu sebagai anggota masyarakat. ${ }^{7}$

Sedangkan menurut ilmu sosiologi masyarakat terbagi menjadi dua yakni sebagai berikut: (1) Masyarakat Tradisional: Masyarakat tradisional adalah masya-rakat yang masih terikat kuat pada tradisi-tradisi (adat istiadat) para leluhurnya secara turun temurun, serta terikat pada alam lingkungannya. Contohnya masya-rakat pedesaan. Tradisinya antara lain: gotong royong, upacara ritual, upacara adat, perkawinan dan sebagainya dan (2) Masyarakat Modern: Masyarakat modern atau kota umumnya diindentikkan dengan masyarakat industri, yang umumnya berada di daerah perkotaan, sebab industri umumnya dibangun di perkotaan.

\section{METODOLOGI PENELITIAN}

\section{Metode Penelitian}

Metode yang digunakan dalam penelitian ini adalah kualitatif. Karena proses penelitian ini lebih bersifat seni (kurang terpola), dan disebut sebagai metode interpretatif karena data hasil penelitian lebih berkenaan dengan interpretasi terhadap data yang ditemukan di lapangan. ${ }^{8}$

Penelitian lapangan ini bersifat deskriptif saja. Sesuai dengan namanya deskriptif yaitu gambaran atau lukisan secara sistematis, faktual dan akurat mengenai fenomena atau hubungan antar fenomena yang diselidiki, menggambarkan sifat suatu keadaan yang sementara berjalan pada saat penelitian,

\footnotetext{
${ }^{7}$ Abu Ahmadi, “Ilmu Budaya Dasar”, Jakarta: Rineka Cipta, 2003, hlm. 109.

${ }^{8}$ Ibid, hlm. 8
} 
dan memeriksa sebab-sebab dari suatu gejala tertentu.

\section{Pengambilan Data}

Dalam pengambilan data ini peneliti melakukan dua sumber data yaitu (1) Sumber data primer. Sumber data primer yaitu data yang paling utama sebagai sumber yang dianggap penting. Adapun yang menjadi sumber data primer dalam penelitian ini adalah wawancara pada Komunitas Suku Dayak Losarang Indramayu. (2) Sumber data sekunder. Sumber data sekunder yaitu sumber data tambahan yang diperoleh dari buku-buku dan sumber lainnya yang ada hubungannya dengan pembahasan penelitian ini yang dijadikan sebagai bahan rujukan.

\section{Lokasi penelitian}

Lokasi penelitian dilakukan pada Komunitas Suku Dayak Losarang Indramayu yang bertempat di Desa Krimun Dusun Tanggul Rt 13/Rw 03 Kecamatan Losarang Kabupaten Indramayu. Sasaran-nya adalah Komunitas suku dayak Losarang.

\section{Teknik Pengumpulan Data}

Adapun teknik pengumpulan data dalam penelitian ini dilakukan dengan cara:

a) Observasi

Observasi adalah metode pengumpulan data dimana peneliti atau kolaboratornya mencatat informasi sebagaimana yang mereka saksikan selama meneliti. ${ }^{9}$ Observasi dilakukan untuk memperoleh informasi tentang kelakuan manusia seperti terjadi dalam kenyataan. ${ }^{10}$ Observasi ini dilakukan untuk mengetahui dan mendapatkan informasi mengenai Ajaran di Komunitas Suku Dayak Losarang Indramayu.

b) Wawancara (Interview)

Wawancara adalah teknik pengumpulan data yang digunakan

\footnotetext{
${ }^{9}$ W. Gulo, “Metodologi Penelitian”, (Jakarta : Grasindo,2002), hlm.116.

${ }^{10}$ S. Nasution, Metode Research, (Jakarta: Bumi Aksara, 1996), hlm. 106.
}

melalui pertanyaan-pertanyaan kepada orang yang berkaitan dan beberapa responden yang berkaitan dengan permasalahan. ${ }^{11}$ Suatu percakapan yang dilakukan untuk mengumpulkan data tentang berbagai hal dari seseorang atau sekumpulan orang, wawancara dilakukan untuk mendapatkan informasi, ${ }^{12}$ tentang Ajaran di Komunitas Suku Dayak Losarang Indramayu.

c) Dokumentasi

Melakukan pengkajian terhadap beberapa dokumen yang berkaitan dengan pelaksanaan penelitian.

e) Pengolahan Data

Pengolahan data yang digunakan dengan penyaksian terhadap peristiwa-peristiwa melihat, mendengar, merasakan yang kemudian dicatat subjektif mungkin. Model observasi yang digunakan dalam penelitian ini adalah observasi partisipan sebagai pengamat, peneliti sebagai pengamat membatasi diri dalam berpartisipasi sebagai pengamat.

\section{HASIL PENELITIAN}

\section{Sejarah Muncul dan Berkembangnya Komunitas Suku Dayak Losarang Indramayu \\ Latar Belakang adanya Komunitas} Suku Dayak Losarang Indramayu tidak lepas dari riwayat hidup pendirinya yaitu Paheran Takmad Diningrat Gusti Alam. Ki Takmad seorang guru pencak silat dan sebagai pemilik padepokan perguruan silat tersebut. Ki Takmad memiliki kemampuan bela diri yang bagus, di samping itu $\mathrm{Ki}$ Takmad adalah seorang dukun yang terkenal karena kemampuannya. Pada waktu itu sekitar tahun 1990 di Desa Krimun ada dua dukun yang terkenal, yang pertama bernama $\mathrm{Ki}$ Takmad dan yang kedua $\mathrm{Ki}$ Karma. Mereka ini ditakuti masyarakat Losarang dan sekitarnya. Ki Takmad juga seorang yang baik dan bijaksana dalam

\footnotetext{
${ }^{11}$ Ibid, hlm.119

${ }^{12}$ Ibid, hlm. 113.
} 
hidupnya. ${ }^{13}$ Kebijaksanan hidup $\mathrm{Ki}$ Takmad yang membuat para anggota dari Komunitas Suku Dayak Losarang Indramayu semakin bertambah. Dia bersikap baik, sopan, dan kejujurannya mempunyai daya tarik tersendiri bagi Komunitas ini. Ki Takmadmengajarkan konsep kemenyatuan diri dengan alam kepada para pengikutnya.

Takmad atau yang bernama lengkap Paheran Takmad Diningrat Gusti Alam lahir pada tanggal 10 Oktober 1940, di Desa Malang Semirang Kecamatan Loh bener Kabupaten Indramayu. Ki Takmad adalah anak laki-laki dari bapak Sardi. Ki Takmad seorang yatim dalam kandungan, ayahnya meninggal ketika $\mathrm{Ki}$ Takmad masih dalam kandungan ibunya pada usia tiga bulan. Ki Takmad pun selama ini hidup dalam kemiskinan, tidak mampu untuk mengikuti pendidikan formal, tidak pernah belajar ilmu agama seperti anak lain seusianya, karena masalah biaya. Oleh sebab itu sekarang Ki Takmad tidak bisa membaca dan menulis, serta tidak begitu fasih dalam berbahasa Indonesia, hanya bisa menguasai bahasa Jawa Indramayu. ${ }^{14}$

Setelah ayahnya wafat, kemudian disusul ibunya. Pada waktu ditinggal wafat oleh ibunya ki Takmad berusia 14 tahun dan selanjutnya dia diasuh oleh kakeknya bernama Ki Darwi. Kakeknya adalah sorang yang menguasai ilmu kesangyangan. Sebagai seorang yang memiliki ilmu kesangyangan dan ingin melestarikan ilmunya itu. Sebelum wafat Ki Darwi mempunyai keinginan menurunkan semua ilmunya pada penerusnya dalam hal ini $\mathrm{Ki}$ Takmad yang menjadi pilihannya. Pada suatu malam Jum'at Kliwon Ki Darwi dan Ki Takmad melakukan sebuah ritual. Ki Takmad diikat dan dilipat dengan kain

\footnotetext{
${ }^{13}$ Wawancara dengan Bapak Wahidin, anggota dari Komunitas Suku Dayak Losarang, pada tanggal 25 oktober 2013 jam 09.00 di Rumah Ki Takmad.

${ }^{14}$ Wawancara dengan Bapak Doble (nama panggilan), salah satu anggota dari Komunitas Suku Dayak Losarang Indramayu, pada tanggal 25 oktober jam 09.30 di Padepokan.
}

kafan dan dimasukan dalam sebuah lemari selama tujuh malam. Setelah dimasukkan $\mathrm{Ki}$ Takmad diharuskan menghisap asap nasi yang baru matang dan air tajen. Setelah ritual tersebut selesai maka terjadi perubahan pada diri Ki Takmad, dia menjadi seorang yang sakti. ${ }^{15}$

Menginjak usia 15 tahun, Ki Takmad bekerja sebagai kuli pelabuhan yang berpindah-pindah dari satu pelabuhan ke pelabuhan lain. Dia belajar ilmu bela diri di beberapa tempat yang disinggahinya. Ketika kembali ke daerah asalnya Loh bener. Ki Takmad menyunting seorang gadis dari desa Krimun dan kemudian memperistrinya. Ki Takmad menikah dengan Sarinih (Sarini Nyi Ratu Giri Warna) itu dikaruniai 11 orang anak, terdiri atas 3 anak perempuan, dan 8 anak laki-laki. Dari kesebelas orang anaknya, 6 di antaranya telah meninggal akibat terkena serangan penyakit. Kini $\mathrm{Ki}$ Takmad hidup bersama istri dan 5 orang anak yaitu, Darto Suhendra, Syarifudin, Dewi Mustika Ratu, Nuryati, dan Sri Penganten Gumilang sari dan dikaruniai empat cucu. ${ }^{16}$

Ki Takmad mengembangkan ilmu yang dimilikinya, baik ilmu kebatinan maupun ilmu kanuragan. Awalnya hanya istri dan anak-anaknya saja yang menjadi pengikutnya, akan tetapi kemudian ada juga beberapa warga masyarakat terdekat menjadi anggota perguruannya. ${ }^{17}$

Ki Takmad mendirikan perguruan yang mengajarkan ilmu kanuragan dengan nama Silat Serbaguna (SS) pada tahun 1974. ${ }^{18}$ Perguruan pencak Silat Serbaguna merupakan salah satu cabang dan diketuai oleh Om Yudon. Kepemimpinan perguruan SS berpindah tangan dari Om Yudon ke Ki Takmad. Kata serbaguna diartikan

\footnotetext{
${ }^{15}$ Wawancara dengan ibu Sarinih, istri dari Ki Takmad pada tanggal 25 Oktober 2013 jam 10.00 di rumahnya.

${ }^{16}$ Wawancara dengan Bapak Warlan, pada tanggal 25 Oktober 2013, jam 10.30 di Rumah Ki Takmad.

${ }^{17} \mathrm{Ibid}$

${ }^{18}$ Ibid
} 
sebagai ilmu yang dipelajari untuk mendapatkan pengasihan, rezeki, digeruni, pelaris, dan untuk mengobati penyakit jasmani dan rohani. ${ }^{19}$ Pada waktu itu perguruan Silat Serbaguna (SS) ini berlokasi di Catur Pinggan Indramayu. Belajar ilmu silat tampaknya lebih mendorong anak didiknya berlaku sombong, karena sudah merasa bisa berkelahi. Beberapa anggota cabang SS banyak yang menyimpang dari aturan perguruan. Diluar, mereka suka berjudi, minuman keras, main perempuan dan berkelahi dengan kelompok lain. Tidak betah dengan kelompok ini, Ki Takmad membubarkan SS. Anggota Perguruan ini cenderung melakukan kesombongan dan ketamakan dalam bersikap dan berperilaku. ${ }^{20}$

Ki Takmad mengumpulkan malingmaling untuk melakukan pencurian dalam segala bentuknya yang kemudian hasilnya diberikan kepada masyarakat yang memerlukan seperti masyarakat yang miskin atau yang kurang makan. Perkumpulan malingmaling ini kemudian disebut dengan Maling Guna. Perguruan silat serbaguna (SS) diganti namanya oleh $\mathrm{Ki}$ Takmad menjadi perguruan Pencak Silat Jaka Utama pada tahun 1976. Jaka utama merupakan nama perkumpulan atau komunitas ke dua dari nama SS, yang dipimpin oleh Ki Takmad Diningrat. Jaka utama itu sebuah pergerakan masyarakat dengan tujuan memperbaiki moral masyarakat serta menjaga kelestarian lingkungan. Pada suatu ketika Ki Takmad melakukan pertapaan selama empat bulan dirumahnya, dan pada suatu malam tanggal 19 November 1996 Ki Takmad mendapat ilham, bahwa ditanah jawa, ditanah Indramayu ini ada woro-woro atau perang saudara dan banjir darah.

"Fatwa bapak kamu harus membuat kebaikan seumur hidup bahwa alam akan

\footnotetext{
${ }^{19}$ Yahya. Op,cit, hlm. 30
}

${ }^{20}$ Wawancara dengan Bapak Roni, dia seorang anggota dari Komunitas Suku Dayak Losarang, pada tanggal 25 April 2013, pada jam 11.00 di Padepokan . berubah, akan ada woro-woro di Indramayu kalau kamu asli manusia tidak akan mati dan itulah manusia seutuhnya". ${ }^{21}$

Ilham tersebut oleh Ki Takmad dianggap sebagai awal dari lahirnya Sejarah Jawa. Setelah mendapat ilham akhirnya Ki Takmad mengganti nama perguruannya dengan Jaka Utama dengan nama Gelar-an Alam (Sejarah adanya Manusia), atau sekarang disebut dengan Komunitas Suku Dayak Losarang Indramayu atau disebut juga dengan Suku Dayak Hindu-Budha Bumi Segandhu. Maka secara otomatis kegiatan dalam perguruan ini menjadi berubah, yang awalnya merupakan sebuah perguruan silat berubah menjadi suatu komunitas tentang kebatinan dengan berguru pada alam. Setelah sekian lama memperdalam ilmu kebatinannya, Ki Takmad pun merasa mendapat pemurnian diri, dari hasil pengkajian ilmu kebatinanya ini, akhirnya menemukan falsafah hidup tentang "kebenaran" yang diyakini dari "Nur Alam" (cahaya alam), yaitu bumi dan langit. ${ }^{22}$ Secara antropologis kebatinan merupakan sistem kepercayaan yang dianut oleh sebagian masyarakat Indonesia khususnya suku jawa. Kebatinan juga bisa disebut dengan kejawen (sebagai gerakan dibidang moral spiritual).

Kata kebatinan akar katanya batin yang berarti di dalam, yang sulit, yang tersembunyi. Batin itu dipakai untuk menunjukan sifat, manusia merasa dirinya lepas dari segala yang semu, batin juga digunakan sebagai sifat keunggulan terhadap perbuatan lahir. Kebatinan adalah sepi ing pamrih rame ing gawe mamayuning bawono. Banyak artinya kebatinan tidak punya pamrih yang menguntungkan diri, melainkan giat bekerja untuk kesejahteraan dunia. ${ }^{23}$ Banyak orang yang masuk dalam komunitas ini dan sekarang berkembang pesat. Anggota dari Komunitas ini ada yang berasal dari desa Krimun dan sekitarnya dan ada juga yang berasal dari

\footnotetext{
${ }^{21}$ Yahya. Op, cit. hlm.50.

${ }^{22}$ Nur Arianata, op, cit. hlm. 26.

${ }^{23}$ Suwarno Imam S. Op, cit. hlm 84
} 
luar kabupaten Indramayu seperti; Subang, Cirebon, Karawang, Tanggerang dan Banten. $^{24}$

Komunitas ini mengajak anggotanya supaya melaksanakan perbuatan yang benar dan menjauhkan diri dari perbuatan salah, baik terhadap sesama manusia maupun terhadap lingkungan. Pergantian ini di-lakukan dengan beberapa alasan yang tujuannya untuk menghindari adanya penyelewengan terhadap arti dan tujuan yang sebenarnya. Awalnya Jaka Utama beranggotakan 20 orang saja, setelah melakukan perenungan dan pertapaan. Ki Takmad yang biasa mengajarkan jurusjurus silat berubah menjadi empu yang bijaksana. Dia mengajarkan nilai-nilai moral dan kebaikan. Setelah bergantinya nama menjadi perguruan Jaka Utama maka perguruan ini berkembang pesat, anggotanya pun menjadi bertambah banyak. ${ }^{25}$

Pembentukan komunitas ini merupakan i'tikad dan upaya Ki Takhmad dalam memperbaiki moral masyarakat. Dalam pergaulan sehari-hari orang mengatakan perihal benar dan salah dalam sikap hidup manusia sering dikenal dengan istilah etika. Etika merupakan ilmu yang yang mem-bahas tentang perbuatan baik dan perbuat-an buruk manusia. ${ }^{26}$ Etika juga bisa diarti-kan sebagai ilmu tentang tingkah laku manusia yang berkenaan dengan ketentuan tentang kewajiban (kebenaran, kesalahan dan kepatuan) dan ketentuan tentang nilai kebaikan dan keburukan. ${ }^{27}$ Jaka Utama mengajak warga masyarakat supaya selalu berbuat baik terhadap sesama manusia maupun lingkungan sekitarnya. Ki Takhmad yang dikenal sebagai jawara silat, kini dia

\footnotetext{
${ }^{24}$ Yahya. Op,cit. hlm. 53-54

${ }^{25}$ Op,cit. Wawancara dengan Bapak Roni, dia seorang anggota dari Komunitas Suku Dayak Losarang Indramayu, pada tanggal 25 April 2013, pada jam 11.30. di

Padepokan .

${ }^{26}$ Cecep Sumarna, Filsafat Ilmu dari hakikat menuju nilai, (Bandung: Pustaka Banib Quraisy, 2004), hlm 127

${ }^{27}$ A Susanto, Filsafat Ilmu, Jakarta: Bumi Aksara, 2011.hlm.175
}

cenderung mengajarkan kebajikan dan kebijakan dalam menyikapi kehidupan. ${ }^{28}$ $\mathrm{Ki}$ Takmad selama memimpin pergerakan itu, terus-menerus melakukan renungan serta pengkajian terhadap berbagai persoalan yang muncul dalam kehidupan masyarakat. Hal ini dikarenakan ki Takmad dipandang sebagai seorang spiritualis baik oleh pengikutnya maupun masyarakat luas. Ki Takmad ada yang memaki sebagai dukun. Komunitas ini mengganti namanya dengan nama Suku Dayak yang bisa diartikan dengan mengayak diri sendiri. Ajaran yang disampaikan pada saat itu adalah bahwa sebelum seseorang mengajarkan orang lain, maka harus mengajar diri sendiri atau melihat kesalahan sendiri. Pada tahun yang sama, nama Suku Dayak berubah menjadi nama Suku Dayak Siswa yang memiliki mazhab belajar, yaitu belajar untuk mengendalikan diri untuk menjadi lebih baik. Mazhab untuk menjadi lebih baik ini mereka sebut dengan Ajaran Ngaji Rasa.

Sebagaimana halnya agama-agama pada umumnya dan aliran pada khususnya sudah dipastikan menimbulkan kebudayaan tertentu baik yang berwujud ritual atau upacara, simbol, tata cara, sikap hidup, falsafah dan pandangan hidup, nilai-nilai moral kesenian. ${ }^{29}$ Relevan dengan tradisi budaya mengenai ritual maupun upacara, maka Komunitas Suku Dayak Losarang Indramayu juga digunakan ritual, upacara. Upacara dilakukan dengan harapan supaya hal-hal yang tidak diinginkan itu tidak terjadi, dan supaya segala sesuatu yang dilakukan, diusahakan dan dihadapi oleh seseorang akan memuaskan sehingga membawa kesuburan dan kesejahteraan serta keselamatan. Upacara biasanya dipimpin oleh kepala Suku, yakni Ki Takmad Diningrat yang bijaksana. ${ }^{30}$

\footnotetext{
${ }^{28}$ Wawancara dengan Bapak Sarwinten. Dia salah satu anggota dari Komunitas Suku Dayak Losarang, pada tanggal 25 Oktober 2013, pada jam 13.00 di Padepokan.

${ }^{29}$ Zakiah Daradjat, "Perbandingan Agama" jilid 1, (Jakarta : Bumi Aksara, 1996), hlm. 37 ${ }^{30}$ Ibid, hlm. 38
} 
Begitupun dalam kenyataannya, kebijaksanaan mempunyai arti dalam kehidupan manusia. Salah satunya kebijaksanaan atau pengetahuan terhadap kebenaran murni itu merupakan suatu pencapaian yang sulit dilakukan, dimana hanya Allah saja yang mampu melakukannya. ${ }^{31}$

\section{Suku Dayak Hindu Budha Segandhu}

Suku Dayak Hindu-Budha Bumi Segandhu merupakan sesuatu yang hanya bisa ditafsirkan pada bahasa Jawa. Pertama arti dari suku, Dalam kamus lengkap bahasa Indonesia moderen suku berarti kaki, berdiri dengan sebelah kaki. ${ }^{32}$ Sedangkan menurut Komunitas Suku Dayak Losarang Indramayu suku bukanlah etnis, melainkan kaki, maksudnya adalah manusia berjalan dan berdiri di atas kaki mereka sendiri, sesuai kepercayaaan dan keyakinan yang dianut serta mempunyai tujuan masing-masing dalam kehidupannya. ${ }^{33}$

Kedua kata Dayak berasal dari kata ngayak yang artinya menyaring berbagai pilihan benar atau salah yang ada dihadapan manusia dalam menjalani kehidupannya. $^{34}$

Ketiga arti dari Hindu ialah rahim atau mengandung. Maksudnya bahwa setiap manusia dilahirkan dari kandungan seorang ibu. Selain itu, mengingatkan setiap manusia akan besarnya peranan ibu atau perempuan dalam mempersiapkan seseorang untuk lahir dan memulai kehidupan. Keempat kata Budha berarti lahir atau dilahirkan tidak memakai apaapa. Maksudnya bahwa manusia dilahirkan dalam keadaan telanjang yang merupakan hakikat hidup manusia yang seharusnya penuh dengan kejujuran dan menyatu dengan alam. Kelima arti dari Bumi ialah wujud keenam Segandu yang

\footnotetext{
${ }^{31}$ Fu'ad Farid Isma'il dan Abdul Hamid Mutawalli, Cara Mudah Belajar Filsafat, (Jogjakarta: IRCiSoD, 2012).hlm.18.

${ }^{32}$ Muhammad Ali. Kamus Lengkap Bahasa Indonesia Modern, ( Jakarta: Pustaka

Amani, 2009), hlm. 467

${ }^{33}$ Ibid

${ }^{34}$ Ibid
}

berarti sewujudnya itu atau sekujur tubuh yang bermakna sebagai kekuatan hidup. ${ }^{35}$

Suku Dayak bukan agama, melainkan adat atau budaya yang selama ini diyakini oleh komunitas yang jauh dari makanan yang bernyawa. ${ }^{36}$ Komunitas Suku Dayak Losarang Indramayu, begitu banyak orang menyebutnya tetapi mereka menamai dirinya dengan Suku Dayak Hindu Budha Bumi Segandhu, yang terletak di Blok Tanggul, Desa Krimun, Kec Losarang, Kab Indramayu. Komunitas ini mulai muncul sekitar tahun 1970-an, memiliki anggota inti sekitar 100 orang dan anggota umum yang tidak terhitung jumlahnya. Anggota umum sendiri tersebar tidak hanya di Indramayu tetapi juga di Subang, Cirebon, Majalengka, Bandung, Bogor dan Jakarta. ${ }^{37}$

Komunitas Suku Dayak Losarang Indramayu ini menempatkan kaum perempuan pada posisi yang sangat terhormat dan sebagai sumber inspirasi. Nyi Dewi Ratu merupakan sebutan personifikasi kekuatan untuk yang maha pemberi hidup atau sumber kehidupan. Nyi Dewi Ratu menguasai hukum-hukum kebenaran atau istilah sejarah alam. Dalam kesehariannya, pemujaan terhadap Nyi Dewi Ratu dipraktekan dalam bentuk kesetiaan terhadap istrinya. Ki Takmad walaupun disegani tetapi dia akan taat apabila berhadapan dengan istrinya. Tidak boleh Berkhianat pada istri (wanita) karena dosa besar yang tidak terampuni. Mereka meyakini terhadap apa yang mereka sendiri percaya. Komunitas Suku Dayak Losarang mempunyai anggota $9.000 .{ }^{38}$

Keberadaan konsep alam, maka pakaian yang dikenakan ialah celana pendek sedengkul yang berwarna sebelah

${ }^{35}$ Op,cit. Wawancara dengan Bapak Rusdi, anggota dari Komunitas Suku Dayak Losarang, pada tanggal 26 Oktober 2013 jam 11.00 di Pendopo.

${ }^{36}$ Ibid

${ }^{37}$ Wawancara dengan Bapak Tarka, dia salah satu anggota dari Komunitas Suku Dayak Losarang. Pada tanggal 26 Oktober, jam 13.00 di Gedung Pendopo.

${ }^{38}$ Ibid 
hitam dan sebelah putih. Pakaian tersebut melambangkan keseimbangan antara alam. Penampilan Komunitas Suku Dayak Losarang Indramayu ini tidak mengenakan baju atau telanjang dada, bercelana pendek dan mengenakan topi seperti petani yang berwarna sebelah hitam dan sebelah putih. Hitam dan putih juga merupakan pembelajaran untuk seimbang karena dengan seimbang akan bisa berjalan terus kehidupannya serta selaras dengan alam. Hitam dan putih merupakan warna dasar sebelum warna-warna lain muncul dan menjadi warna dasar atau warna alam. ${ }^{39}$

Rambutnya dibiarkan panjang dan di cat warna putih. Tetapi semua itu merupakan keyakinan diri sendiri untuk mengecat rambut mereka. Memanjangkan rambut merupakan kewajiban dari komunitas ini. Aksesoris yang dikenakan merupakan perjalanan dari hasil spiritual orang tua. Gelang yang dipergunakan terbuat dari kajelik yang di untai-untai menghasilkan gelang. Ikat pinggang yang mereka pakai terbuat dari kayu. Ikat pinggang tersebut mempunyai 32 keping yang terdiri dari 25 keping yang terinspirasi dari 25 nabi dan 5 keping yang terinspirasi dai pandawa lima atau pewayangan yaitu Yudistira, Bima, Arjuna, Nakula dan Sadewa dan 2 keping yang bergambarkan gunung. Kalung terbuat dari pohon gali asem yang tumbuh dari ribuan tahun yang lalu. Kalung tersebut salah satunya berbentuk garuda. Menurut mereka, garuda di buatnya dari atas ke bawah dan jangan sebaliknya karena pemerintah seharusnya melihat ke bawah pada masyarakat yang kurang mampu. ${ }^{40}$

Komunitas Suku Dayak Losarang Indramayu ini berjiwa sosialis, toleran, dan bebas. Dari dulu Sampai sekarang, Komunitas ini masih mengikuti adat Kuno. Dalam mengkonsumsi makanan contohnya diharuskan alami berasal dari alam, tidak

\footnotetext{
${ }^{39}$ Ibid

${ }^{40}$ Wawancara dengan Bapak Tomad, anggota dari Komunitas Suku Dayak Losarang, pada tanggal 27 Oktober 2013 jam 10.00 di Pendopo.
}

dicampuri bahan-bahan buatan luar, apalagi mengandung zat kimia, dan Komunitas ini tidak mengikuti agama manapun, seperti halnya agama-agama lain, seperti Islam, Kristen, Yahudi dan sebagainya. Meski masih tetap tercampuri sedikit budaya Hindu Budha, sesuai dengan nama sukunya. Namun memiliki pegangan tersendiri dan lebih pada istilah Komunitas yang independen yang dikepalai oleh pemimpinnya. ${ }^{41}$

Komunitas ini lahir secara turun temurun dan berubah-ubah, dulu namanya Pewayangan. Mengambil dari keteladanan tokoh para wayang, seperti Semar, dan Pandawa Lima, kemudian Kesanghyangan, berganti lagi menjadi Kerajaan, baru adanya sedikit yang mengarah pada nama Agama itu di era sekarang ini, yakni bernama Jawa Agama. Sementara anggota inti yaitu orang-orang yang menjalani syariat atau laku sesuai dengan yang diyakini penghuni komunitas Bumi Segandhu. Laku itu ditunjukkan dalam bentuk melepaskan badan dari atribut keduniawian, ditunjukkan dengan cara berpenampilan yang bertelanjang dada. Anggota inti hanya bercelana, itu pun warnanya khas yaitu hitam-putih. Ciri lainnya, yaitu memasang berbagai manikmanik yang terbuat dari bambu dan kayu, berupa kalung, gelang tangan dan kaki. Selain itu, terdapat juga yang memakai kain hitam untuk menutupi kepala dan bila bepergian, mereka menggunakan topi terbuat dari anyaman bambu berbentuk trapesium. ${ }^{42}$

Pada tahap selanjutnya, Ki Takmad mulai mengajarkan apa yang dia temukan kepada beberapa orang yang tertarik, sehingga lama-kelamaan terciptalah sebuah komunitas yang menghormati apa yang diajarkan oleh ki Takmad. Komunitas ini semakin dikenal oleh masyarakat luar, bah-kan mulai menarik perhatian dari

\footnotetext{
${ }^{41}$ Wawancara dengan Bapak Durakim, anggota dari Komunitas Suku Dayak Losarang, pada tanggal 27 Oktober 2013 jam 11.00 di Pendopo

${ }^{42}$ Ibid
} 
pemerin-tahaan pada waktu itu. Dengan menuai pro dan kontra, komunitas ini tetap ada dan melakukan aktivitas seperti biasa, entah sampai kapan.

Komunitas Suku Dayak Losarang ini memiliki cara khusus untuk melatih anggotanya dalam mengendalikan diri yaitu dengan berendam di parit semalam suntuk hingga 30 malam. Meski memakai nama dan berpenampilan mirip dayak, namun mereka tidak memiliki hubungan dengan suku dayak di Kalimantan. ${ }^{43}$

\section{Ritual Suku Dayak Losarang \\ a) Ritual Kungkum}

Ritual kungkum sudah dijelaskan tadi diatas, tetapi penulis ingin mengulasnya lagi sedikit tentang ritual ini. Disebut kungkum ini dilakukan semalam suntuk. Rutinitas anggota Komunitas ini pada saat malam mereka berendam di sungai. Selama berendam mereka dianjurkan untuk merenungi kebesaran Sang Pencipta. Ritual ini bertujuan untuk menciptakan kesabaran walaupun dalam keadaan yang sulit. Ritual ini dilakukan selama 30 malam berturut-turut. Namun tidak seluruh anggota Komunitas Suku Dayak Losarang mampu menjalankannya. Bagi yang mampu status sosialnya dianggap lebih tinggi. Dalam kesehariannya 400 anggota Komunitas Suku Dayak Losarang memilih menjadi vegetarian dan bekerja sebagai petani. ${ }^{44}$

\section{b) Ritual Pepe}

Komunitas Suku Dayak Losarang Indramayu menjalankan ritual pepe. Ritual pepe adalah kegiatan mereka pada pagi hari, berjemur sambil menikmati udara pagi dan terik matahari. Tradisi pepe atau berjemur yang merupakan salah satu ajaran dari Ki Takmad. Pepe merupakan salah satu dari empat ritual yang biasa dilakukan sehari-hari, yang dilakukan pada siang

\footnotetext{
${ }^{43}$ Ibid

${ }^{44}$ Op.cit. Wawancara dengan Ki Takmad pada tanggal 27 Oktober 2013 jam 16.00 di Rumahnya.
}

hari disaat sinar matahari sedang terik, berlang-sung mulai jam 09.00 hingga tengah hari, bertempat di lapangan depan padepokan. Posisi awal setiap anggota berdiri membentuk lingkaran dan saling berpegangan, kemudian membaca pujian. Selesai membaca pujian mereka tidur terlentang posisi masih membentuk lingkaran. ${ }^{45}$

\section{c) Ngaula Ning Anak Rabi}

Komunitas Suku Dayak Losarang. Laki-laki itu Ngaula ning anak rabi, maksudnya itu mereka mengabdikan hidup mereka kepada istri dan anaknya. Karena perempuan itu sebagai ratu. Komunitas ini menempatkan kaum perempuan pada posisi yang paling dihormati dibandingkan dengan kaum laki-laki, sekaligus sebagai sumber inspirasi. Nyi Dewi Ratu demikian sebutan personifikasi kekuatan untuk yang maha pemberi hidup atau sumber kehidupan. Bahkan pintu bangunan pendopo komunitas ini, berreliefkan Nyi Dewi Ratu Kembar.Pekerjaan yang biasa dilakukan oleh perempuan pun, dikerjakan oleh suaminya. Seperti masak, dan lainnya. Mereka mempunyai prinsip jangan sampai menyakiti seorang perempuan karena mereka sadar kalau mereka lahir dari seorang Perempuan. $^{46}$

\section{d) Ritual Ruatan Putri Keraton}

Kegiatan Ruatan Putri Kraton dalam Komunitas Suku Dayak Losarang Indramayu ini sebenarnya merupakan serangkaian acara yang bersifat simbolisasi mengenai ajaran $\mathrm{Ki}$ Takhmad, bahwa segala sesuatunya dikembalikan kepada masing-masing individu manusia. Ritual ini dilakukan sebagai sambung tangan dan sambung rasa (persaudaraan) antara Suku Dayak Losarang Indramayu dengan siapapun, baik individu dalam masyarakat sekitar maupun masyarakat lainnya. ${ }^{47}$

\footnotetext{
${ }^{45}$ Ibid

${ }^{46}$ Ibid

${ }^{47}$ Ibid
} 
Kegiatan ini dimulai tanggal 1826 Februari 2009. Seminggu pertama awalnya diisi dengan pameran adat dan budaya dari masing-masing komunitas adat yang diundang. Kemudian dilanjutkan dengan kegiatan inti yaitu Ruatan Putri Kraton, dan hari terkahir ditutup dengan pertunjukan wayang kulit kepada masyarakat sekitar. Acara arak-arakan Ruatan Putri Kraton yang bersifat simbolis inipun, sebenarnya hanya diisi de-ngan atraksi reog atau wayang uwong kemudian diisi pula dengan atraksi kebo ngamuk sebagai lambang karakter masing-masing manusia. Sehingga diharapkan dapat menggambarkan bagaimana seharusnya keharmonisan antar manusia, baik dengan manusia lainnya maupun dengan alam dapat terwujud. Terlepas dari makna kegiatan tersebut, kegiatan ini relatif berjalan baik, karena antusiasme dan partisipasi masyarakat sekitar cukup tinggi. ${ }^{48}$

Tujuan diadakannya kegiatan ini yaitu untuk memperkuat tali persaudaraan dan tali silaturahmi, baik antara ki Takhmad dengan masyarakat sekitar maupun para tamu undangan, karena sebagian yang diundang juga merupakan masyarakat adat, seperti Suku Baduy, Komunitas Cigugur, Himpunan Pengawas Kepercayaan (HPK) dan Aliansi Bhinneka Tunggal Ika. Kegiatan ini dimulai tanggal 18-26 Februari 2009. Seminggu pertama diisi dengan pameran adat dan budaya dari masingmasing Komunitas adat yang diundang. Kemudian dilanjutkan dengan kegiatan inti yaitu Ruatan Putri Kraton, dan hari terkahir ditutup dengan pertunjukan wayang kulit kepada masyarakat sekitar. Acara arak-arakan Ruatan Putri Kraton yang bersifat simbolis ini, sebenarnya hanya diisi dengan atraksi reog atau wayang uwong kemudian diisi pula dengan atraksi kebo ngamuk sebagai lambang karakter masing- masing manusia. Sehingga diharapkan dapat meng-gambarkan bagaimana seharusnya keharmonisan antar manusia, baik dengan manusia lainnya maupun dengan alam dapat terwujud.

\section{e) Pemurnian Diri}

Jalan menuju pemurnian diri juga ditunjukan dengan hidup yang sederhana, menjauhi keinginan mengejar kesenangan duniawi, menghilangkan perasaan dendam, penasaran dan iri kepada orang lainnya. Konsepsi tentang alam tampak dari keyakian bahwa dunia berasal dari bumi segandu (bumi yang masih bulat) bernama Indramayu Bumi segandu, kemudian menim-bulkan lahar menjadi daratan, kekayon, dan air. Setelah itu muncul alam gaib, yang mengendalikan semua itu adalah Nur Alam. ${ }^{49}$

\section{f) Ritual Malam Jumat Kliwon}

Setiap malam Jum'at Kliwon, bertempat di Padepokan Krakatau. Kurang lebih jam 07.00 anggota dari Komunitas Suku Dayak Losarang, mempersiapkan diri untuk melakukan ritual yang biasa dilakukannya. Kegiatan ini dilakukan secara massal. Semua laki-laki memasuki Padepokan satupersatu, duduk mengelilingi sebuah kolam kecil di dalam padepokan. Dalam pelaksanaannya, ada dua orang perempuan setengah baya merapihkan sesaji kembang tujuh rupa, dan tujuh buah gelas berisi aneka minuman seperti; air putih, kopi, teh, bajigur, dan lain-lain.

\section{Nilai Karakter Suku Dayak Losarang}

a) Pokok-pokok Ajaran Ngaji Rasa ${ }^{5}$

Setiap aliran kebatinan pada umumnya masing-masing mempunyai pokok-pokok ajaran atau sistem keyakinan. Sistem keyakinan ini dapat berwujud pikiran dan gagasan manusia, yang mencakup keyakinan dan konsepsi

\footnotetext{
${ }^{49}$ Op,cit. Wawancara dengan Ki Takmad pada tanggal 27 Oktober 2013 jam 16.00 di Rumahnya.

${ }^{50}$ Ibid

51 Yahya, op,cit. hlm. 53
} 
manusia tentang sifat-sifat Tuhan, tentang wujud dari alam gaib (kosmologi), tentang terjadinya alam semesta (Kosmogoni), tentang zaman akherat (esyatologi), tentang wujud dan ciri-ciri kekuatan sakti. D bawah ini bentuk ngaji rasa, yaitu :

1) Ajaran tentang Tuhan dan Manusia Menurut Komunitas Suku Dayak Losarang Indramayu Tuhan itu ada pada setiap pribadi manusia. Ia hadir dalam hati, dalam sertiap gerak langkah dan perbuatan manusia. Dengan demikian, karena penganut aliran ini menganggap bahwa mereka mengaku dirinya Tuhan maka hubungan dengan Tuhan tidak diutamakan. Jadi cukup dengan menyayangi dan berbuat baik dengan sesama. Dalam ajaran Komunitas Suku Dayak Losarang, manusia apabila sudah meninggal dunia maka ia telah menjadi sesuatu yang tidak lagi mempu-nyai nilai, ia menjadi bangkai dan dalam Ngaji Rasa tidak mengenal hari akherat, tidak ada surga dan neraka. Manusia hanya hidup dalam dunia nyata, istilah surga dan neraka hanya merupakan sebuah simbol kebaikan dan kejahatan, kebahagiaan dan kesengsaraan. $^{52}$

2) Ajaran Tentang Kejadian Alam Semesta

Alam menurut Komunitas ini, awalnya sebelum alam terjadi keadaan dijagat raya tidak ada apa-apa atau kosong, keadaan ini tidak bisa dibayangkan seperti apa. Ketika ki Takmad pertama kali dalam pertapaannya menda-pat ilham, yaitu lahir sejarah jawa, bahwa dijawa ini ada woro-woro. Komunitas ini tidak mengenal istilah alam akherat (surga dan neraka) mereka berpendapat bahwa surga dan neraka merupakan sesuatu yang tidak wujud. Kehidupan hanya ada pada alam nyata

\footnotetext{
${ }^{52}$ Ibid hlm. 56
}

(kehidupan duniawi), meninggalnya seseorang menurut mereka merupakan batas akhir dari kehidupan tersebut. ${ }^{53}$

3) Ajaran Tentang Etika

Ajaran tentang etika menurut Komunitas Suku Dayak Losarang bertujuan untuk menempuh budi luhur di dunia ini serta berusaha menciptakan masyarakat yang berdasarkan saling menghargai dan mencintai dengan senantiasa mengindahkan hal-hal kebaikan. Ajaran tentang etika dalam Ngaji Rasa yang diambil adalah benar dan salah, diutamakan terhadap seorang istri dan anak, istri dan anak merupakan guru bagi seorang suami untuk mencapai manusia yang sempurna.

\section{b) Tentang Etika dan Budi Pekerti}

1) Sabar

Sabar diartikan sebagai suatu keadaan jiwa yang kokoh, stabil, dan konsekuen dalam pendirian. ${ }^{54}$ Jiwanya tidak goyah, pendiriannya tidak berubah bagaimanapun berat tantangan yang dihadapi dalam hidupnya. Begitupun dalam Komunitas Suku Dayak Losarang Indramayu ini memaknai sabar ialah luas hati dan kuat dalam menghadapi segala macam cobaan yang menimpa dirinya, segala penderitaan yang dialami didunia. Kesabaran merupakan jalan mencapai tujuan, tidak merupakan niat yang berhenti ada angan-angan saja, tetapi sabar melaksanakan apa yang diniatkan dengan tekun dan ulet sampai berhasilnya tujuan itu. Contoh dalam ritual pada Komunitas ini adalah tapa ning banyu (bertapa dalam air) selama empat bulan, ritual ini dilakukan setiap malam. Dalam ritual ini para anggota dari Komunitas Suku Dayak Losarang Indra-

\footnotetext{
${ }^{53}$ Ibid, hlm. 57

${ }^{54}$ M. Solihin, dan Rosihon Anwar. Ilmu Tasawuf, (Bandung: Cv Pustaka Setia, 2008), hlm. 118
} 
mayu di uji kesabarannya dalam melawan dinginnya malam dan air sungai yang menyelimuti badan. ${ }^{55}$

2) Jujur

Komunitas Suku Dayak Losarang Indramayu mengajarkan kejujuran, tidak boleh berbohong kepada orang tua, kepada sesama anggota dan juga yang bukan anggota dari komunitas ini. Orang yang berbohong berarti ia mengotori dirinya sendiri dan tidak menepati kewajiban dan janji. Kejujuran akan mendatangkan keadilan, keadilan membawa kemulyaan abadi dan disamping itu kejujuran memberikan keberanian dan ketentraman hati. ${ }^{56}$

3) Nerima

Istilah nerima sama dengan rida, yang artinya menerima dengan lapang dada dan hati terbuka terhadap apa yang datang dari Tuhan. ${ }^{57}$ Nerima itu tidak merasa iri hati akan hasil kekayaan orang lain, bu-kan segan atau malas bekerja, akan tetapi rasa puas terhadap apa yang sudah menjadi bagiannya, kekayaan dan kepuasan hendaknya dicari dalam sifat nerima, orang akan menjadi kaya dan paling bahagia bila memiliki sifat ini. Sifat nerima akan membawa seseorang pada ketentraman hati. ${ }^{58}$

4) Lakonana Barang Kang Lima ( melaksanakan Perkara yang lima)

Lakonana barang kang lima yaitu dengan melaksanakan sabar, jujur, benar dan nerima. Dari keempat sifat ini harus dilaksanakan dan tidak hanya dalam ucapan, tetapi juga harus dijalankan dalam kehi-

\footnotetext{
${ }^{55}$ Yahya, Op,cit. hlm. 58

${ }^{56} \mathrm{Ibid}$

57 M. Solihin, dan Rosihon Anwar. Op,cit. hlm. 119

${ }^{58}$ Op,cit. Wawancara dengan Ki Takmad Diningrat (kepala suku dayak losarang), di rumahnya pada tanggal 26 November 2013 , jam 10.00 .
}

dupan sehari-hari. ${ }^{59}$ Orang yang hanya mengucapkan tetapi ia tidak menerapkannya dalam kehidupan, maka orang itu tidak berguna, tetapi apabila semuanya itu dijalankan, maka orang akan selalu merasa hidupnya tenang dan tentram dan ia akan menjadi manusia seutuhnya sepanjang masa. ${ }^{60}$

\section{SIMPULAN}

Setelah melakukan studi lapangan tentang karakter di suku dayak Losarang Kab. Indramayu, maka dapat di simpulkan sebagai berikut :

- Jenis nilai yang masih di internalisasikan oleh warga masyarakat Suku Dayak Losarang kabupaten Indramayu adalah ngaji rasa yaitu sistem keyakinan juga mencakup sistem nilai dan sistem norma keagamaan, ajaran kesusilaan, dan ajaran doktrin religi lainnya yang mengatur tingkah laku manusia. Sistem keyakinan tersebut biasanya terkandung dalam kasusatraan suci, baik yang sifatnya tertulis maupun lisan. Ajaran ngaji rasa dalam mewujudkan pikiran dan gagasan yang menyangkut masalah keyakinan tertuang dalam beberapa pokok ajaran.

- Proses Suku Dayak Losarang kabupaten Indramayu dalam menginternalisasi nilai yang diyakini yaitu mengajarkan tentang Etika dan Budi Pekerti menitik beratkan pada lima pokok, yaitu sebagai berikut: sabar, jujur, bener, nerima dan lakonana barang kang lima.

- Peran pemimpin/kepala Suku Dayak Losarang kabupaten Indramayu dalam menjaga dan melestarikan nilai-nilai lokal sangatlah besar pengaruhnya yaitu dengan mengumpulkan sejumlah anggotanya pada malam jum'at keliwon untuk bermeditasi diantaranya kungum dan mepe awak.

\footnotetext{
${ }^{59}$ Ibid

${ }^{60} \mathrm{Ibid}$
} 
- Bentuk karakter yang mereka miliki sebagai hasil dari proses internalisasi nilai adalah menjadi orang yang sabar dan menyatu dengan alam artinya kita tidak boleh menyakiti sesama makluk tapi harus menyanyanginya.

- Keuntungan bagi masyarakat adat adalah mereka bisa mempertahankan ideologi dari turun temurun dari mulai Ki Takmad sampai sanak saudaranya sementara kerugiannya adalah mereka berada pada minoritas kehidupan. Hal ini terlihat dari cara berpakaian yang berbeda hanya memakai celana yang berwarna hitam dan putih saja.

- Faktor pendorong (push factors) dan faktor penarik (pull factor) yang membuat mereka bertahan dalam kelompok masyarakat adat adalah mereka melakukan beberapa ritualnya yaitu : a) Ritual Kungkum, b) ritual pepe, c) ngaula ning anak rabi, d) ritual ruatan putri keraton, e) pemurnian diri, dan f) ritual malam jumat kliwon

- Ekspektasi suku dayak Losarang Kab. Indramayu terhadap perubahan nilainilai sosial diluar komunitasnya yaitu agar warga sekitarnya melindunginya dengan mendukung kegiatan ritualnya.

- Nilai-nilai luar dari suku dayak Losarang kab. Indramayu menjadi ancaman atas eksistensi dari ajarannya. Hal ini terlihat dari ada beberapa para pengikut dari ajarannya ki Takmad pindah atau keluar dari ajarannya/komunitasnya.

- Ada beberapa nilai dari suku dayak Losarang Kab. Indramayu yang mungkin bisa dipromosikan ke masyarakat luar yaitu sabar, jujur, bener, nerima dan lakonana barang kang lima.

\section{DAFTAR PUSTAKA}

Aan Hasanah. 2013. Pendidikan Karakter berprspektif Islam. Bandung. Penerbit Insan Komunika

Abdul Majid, dan Dian Andayani, (2011). Pendidikan karakter Perspektif Islam. PT. Remaja Rosdakara. Bandung.
Achmad Maulana dkk, Kamus Ilmiah Populer, (Yogyakarta: Absolut, 2004).

Abdullah, Irwan. 2002. Simbol, Makna dan Pandangan Hidup Jawa, Yogya-karta. Balai Kajian Sejarah dan Nilai Tradisional

Ali, Muhammad. 2009. Kamus Lengkap Bahasa Indonesia Modern, Jakarta: Pustaka Amani.

Albayanuniy, Izzuddin. 1994. Hati, Jakarta: Granada Nadia.

Arianata, Nur. 2013. Konsep Ketuhanan dalam Ajaran Komunitas Suku Dayak Hindu-Budha Bumi Segandhu Indramayu. Cirebon : Skripsi Program Sarjana IAIN Syekh Nurjati Cirebon.

Bagus Mustaqim, (2011). Pendidikan Karakter Membangun delapan karakter emas menuju Indonesia Bermartabat. Yogyakarta: Samudra Biru.

Dharma Kesuma dkk. (2012). Pendidikan Karakter: Kajian teori dan praktik di sekolah. PT. Bandung: Rosdakarya.

Doni Koesoema, Pendidikan Karakter; Strategi Mendidik Anak di Zaman Global, (Jakarta: Grafindo, 2007).

Daradjat, Zakiah.1996. Perbandingan Agama, jilid 1, Jakarta : Bumi Aksara.

Farid, Isma'il Fu'ad dan Hamid, Mutawalli Abdul. 2012. Cara Mudah Belajar Filsafat : Jogjakarta: IRCiSoD

Gunawan, Adi. 1996. Menurut Kamus Praktis Ilmiah Populer. Surabaya: Kartika.

Gulo, W. 2002. “Metodologi Penelitian”, Jakarta : Grasindo.

H.A.R. Tilaar (2000). Beberapa Agenda Reformasi Pendidikan Nasional dalam perspektif Abad 21. Penerbit Tera Indonesia.

Ilyas, Abd. Mutholib dan Abd Ghofur Imam. 1988. Aliran Kepercayaan dan Kebatinan di Indonesia, Surabaya : Cv. Amin Surabaya.

Imam, Suwarno. 2005. Konsep Tuhan, Manusia, Mistik Dalam Berbagai 
Kebatinan Jawa, Jakarta: PT Raja Grafindo Persada

Lickona, Thomas. 2013. Mendidik untuk membentuk karakter. Jakarta. Bumi Aksara.

2013. Character Matters : persoalan. Jakarta. Bumi Aksara.

Jalaluddin, 2005. Psikologi Agama, Jakarta: Rajawali Pers.

Kemendiknas. (2010). Pembinaan Pendidikan Karakter di Sekolah Menengah Pertama. Jakarta

Kementrian Agama. 2012. Penciptaan Manusia , Jakarta : Kementrian Agama RI.

Koentjoroningrat. 1987. Sejarah Teori Antropologi, Jakarta : Universitas Indonesia-Press.

Kiswati, Tsuroya. 2002. Al-Juwaini Peletak Dasar Teologi Rasional dalam Islam: Jakarta: Erlangga.

Muzairi. 2009. Filsafat Umum, Yogyakarta : Teras.

Nasution, S. 1996. Metode Research, Jakarta : Bumi Aksara.

Pals, L Daniel., 2001. Dekonstruksi Kebenaran Kritik Tujuh Teori Agama Yogyakarta : IRCiSoD

Rais, Marzuqi,2009. Sejarah Alam Ngaji Rasa Suku Dayak Hindu Budha Bumi Segandhu Indramayu, dalam http://www.fahmina.com,

Sadily, Hassan. 1993. Sosiologi, Jakarta : PT Rineka Cipta.

Solihin, M. dan Rosihon Anwar. 2008. Ilmu Tasawuf. Bandung: Cv Pustaka Setia

Soehadha, Moh. 2006. Teori Simbol Victor Turner, Aplikasi dalam Implikasi dan metodologisnya untuk study Agama-Agama, dalam Jurnal Esensia Volume 7.
Soedjono, D. 1982 . Sosiologi Suatu Pengantar Untuk Masyarakat Indonesia, Bandung : Alumni.

Sugiyono. 2009. Metode Penelitian Kuantitatif Kualitatif dan $R \& D$, Bandung : Alfabeta, cv.

Susanto, A. 2011. Filsafat Ilmu, Jakarta: Bumi Aksara.

Suhendra, 2009. Suku Dayak Hindu-Budha Bumi Segandu Indramayu.

Said, Abdul Azis. 2004. Simbolisme Unsur Visual Rumah Tradisional Taraja dan Perubahan Aplikasinya pada Desain Modern, Yogyakarta : Ombak.

Supriadi. 2006. Etika dan Tanggung Jawab Profesi Hukum di Indonesia: Jakarta: Sinar Grafika.

Sumarna, Cecep . 2004. Filsafat Ilmu dari hakikat menuju nilai, Bandung: Pustaka Banib Quraisy.

Suseno, Franz Magnis. 2001. Etika Jawa, Jakarta: PT Gramedia Pustaka Utama.

Tafsir, Ahmad. 2009. Filsafat Umum, Bandung: PT Remaja Rosdakarya.

Tafsir Ilmi, 2012. Penciptaan Manusia, Jakatra :Kementrian Agama RI

Yahya, 2007 " Interaksi sosial antara masyarakat penghayat aliran kebatinan sejarah alam ngaji rasa dengan masyarakat sekitarnya" Bandung : Skripsi Program Sarjana UIN SGD Bandung. 